\title{
Intraday Predictability of Overnight Interest Rates
}

\author{
Young-Sook Lee
}

\author{
School of Economics \\ University of Nottingham
}

Revised: September 2001

\begin{abstract}
Lee (2001) found that the overnight Eurodollar rate in London and the effective Fed funds rate exhibit similar calendar day effects although the absolute magnitudes are slightly less. The excess return on overnight Eurodollars over Fed funds is predictable based on the lagged overnight Eurodollar rate, the lagged Fed funds rate and calendar day dummies. Explanations for the smaller calendar day effects on the overnight Eurodollar rate at 11:00 am GMT than on the effective Fed funds rate, and the predictable excess return include the difference between market-specific conventions in the two markets and the time difference in measuring the two overnight interest rates. This paper investigates the relationship between the Fed funds rate at 11:30 am EST, the effective Fed funds rate and the overnight Eurodollar rate in London. It is found that the predictable excess return is caused by both the difference between the market structures and by the measuring time difference.
\end{abstract}

JEL classification: E44; G15; G21

Key words: Overnight Eurodollar rate; Fed funds rate; Calendar day effects; Intraday interest rate

Young-Sook Lee

School of Economics

University of Nottingham

University Park

Nottingham NG7 2RD

U.K.

Tel) 01158466715

Fax) 01159514159

E-mail)young-sook.lee@nottingham.ac.uk 


\section{Introduction}

This paper closely investigates the relationship between the overnight Eurodollar rate and the Fed funds rate documented by Lee (2001). Lee (2001) finds that the overnight Eurodollar rate and the effective Fed funds rate exhibit similar calendar day effects even though not with exactly same rates. The overnight Eurodollar rate and the effective Fed funds rate decrease on Fridays and before U.S. holidays. They both increase on Mondays, after U.S. holidays and on settlement Wednesdays. However, the calendar day effects on the conditional mean of the overnight Eurodollar rate are smaller than those effects on the conditional mean of the Fed funds rate. The conditional variances of the Fed funds rate and the overnight Eurodollar rate tend to increase as settlement Wednesday approaches and are highest on settlement Wednesday. These results indicate that the overnight Eurodollar rate is affected by Federal Reserve regulations and accounting conventions even if some participants do not hold reserves in the U.S. to meet U.S. reserve requirements over the two week reserve maintenance period and do not trade in the Fed funds market.

The overnight Eurodollar rate in London and the effective Fed funds rate used in Lee (2001) are collected at the different times: the overnight Eurodollar rate is for the time between 7:00 am and 8:00 am Eastern Standard Time (EST) and the effective Federal funds rate is a weighted average of the Federal funds rate during the day in the U.S. Spindt and Hoffmeister (1988) exhibit a model where the variance of the Fed funds rate varies within a day and becomes higher toward the end of each business day and is highest at the end of settlement Wednesday. Griffiths and Winters (1995) empirically show that the afternoon high rates and the afternoon low rates fall significantly over the maintenance period. However, the morning high rates and the morning low rates tend to fall in the first week and remain statistically unchanged throughout the remainder of the maintenance period. On settlement Wednesday, the afternoon low rates remain statistically unchanged but the afternoon high rates increase significantly. They also show that the afternoon variances are larger than the morning variances but predictable patterns in their variance changes are very similar. They conclude that the variance generating process in the morning is different from the process in the afternoon. Based on Spindt and Hoffmeister (1988) and Griffiths and Winters (1995), the predictability of 
the differential between the Fed funds rate and the overnight Eurodollar rate in Lee (2001) might be because the two rates are collected at different times.

There is some literature investigating the joint time series behavior of asset returns in the Fed funds market and other short-term financial markets in the U.S. Ho and Saunders (1985) develop a model to explain the typically positive spread between the Fed funds rate and other short-term money market rates. Their model assumes that a bank's demand for Fed funds is submitted at a point in time prior to the time when the bank closes its books and that the timing interval is very small. Therefore, the bank can not use other market methods such as Eurodollars, repos and T-bills to adjust reserves. Griffiths and Winters (1997) note that overnight government repos exhibit daily rate change and daily variance patterns consistent with patterns identified in the Fed funds market. However, the effects of the Fed Reserve regulation are less in the government repo market. On the other hand, rates on Government National Mortgage Association (GNMA) repos do not change as the Fed funds rate changes even though they could potentially be used as a substitute for Fed funds transactions. This suggests that the GNMA repos are not used for settlement purposes. They use daily closing bid side broker quotes for the overnight repo rate and for the overnight Fed funds rate. Explanations for the smaller effects of calendar days on the overnight Eurodollar rate in London than on the effective Fed funds rate documented by Lee (2001) are either the differences between market-specific conventions in the two money markets or time differences.

This paper investigates the calendar day effects on the Fed funds rate at 11:30 am. The results suggest that the predictable excess return is caused by both the difference between the two market structures and by the time difference in measuring the two overnight interest rates. Thus, the effects of calendar days on the overnight Eurodollar market, which are smaller than those on the Fed funds rate, are not only due to line limits and accounting conventions in the Fed funds market affecting both the Fed funds market and the overnight Eurodollar market but also due to unique features in the overnight Eurodollar market (different participants, location differences and different transaction volume). The true ex ante predictable excess return on the overnight Eurodollars over 
the Fed funds would not be as large as the excess return estimated with the data used in Lee (2001).

This paper proceeds as follows. The data are described in Section II. Section III describes my empirical methodology, and Section IV reports the empirical results. The conclusion is presented in Section $\mathrm{V}$.

\section{Data}

Lee (2001) used the effective Fed funds rate for the Fed funds rate and the overnight London Interbank Offer Rate (LIBOR) at 11:00 am Greenwich Mean Time, which corresponds to 6:00 am Eastern Standard Time (EST), for the overnight Eurodollar rate. While the effective Fed funds rate is a weighted average of lending rates over the day, the overnight LIBOR is a point-in-time observation before the Fed funds market opens. Therefore, these two overnight interest rates are measured differently.

Because the Fed funds rate and the overnight Eurodollar rate are different in locations and measured times, the predictability of the differential between the Fed funds rate and the overnight Eurodollar rate might be driven by market differences or by the time differences in measuring data. To investigate the reasons, this paper analyzes the calendar-day effects on the Fed funds rate at 11:30 am and the differential between the effective Fed funds rate and the Fed funds rate at 11:30 am.

Data on Fed funds rates at 11:30 am were obtained from the Federal Reserve Bank of New York. ${ }^{1}$ The rate is the observed rate on the broker's screen shortly before 11:30 am. The period analyzed runs from March 1, 1984 to September 8, 1995 because of data availability. Throughout this period the Fed employed contemporary reserve requirements and used a two-week maintenance period. Required reserves are calculated during the computation period, a two-week period beginning on Tuesday and ending on Monday. A bank satisfies the reserve requirement during the two-week maintenance period ending on Wednesday, two days after the computation period.

Panel A of Figure 1 presents the effective Fed funds rate $\left(i_{t}\right)$ and panel $\mathrm{B}$ of Figure 1 presents the Fed funds rate at 11:30 am $\left(i_{t}^{11}\right)$. Panel $\mathrm{C}$ of Figure 1 plots the differential 
between the Fed funds rate at 11:30 am and the effective Fed funds rate $\left(i_{t}^{11}-i_{t}\right)$. The effective Fed funds rate and the Fed funds rate at 11:30 am move very similarly, just as the effective Fed funds rate and the overnight Eurodollar rate do. Table I shows summary statistics of the effective Fed funds rate and the Fed funds rate at 11:30 am from March 1984 to September 1995. The Fed funds rate at 11:30 am is 2 basis points lower than the effective Fed funds rate on average. The standard deviation of the Fed funds rate at 11:30 am is smaller than that of the effective Fed funds rate. The biggest changes occur at the same time, the end of 1985 and at the end of 1986, for both the Fed funds rate at 11:30 am and the effective Fed funds rate. The morning rate increases less than the effective Fed funds rate at the end of 1985 but more at the end of 1986. Kurtosis of the change in the effective Fed funds rate and the change in the Fed funds rate at 11:30 am are very large, 135 and 266 respectively, because of infrequent big changes. Therefore large kurtosis should be considered in the analysis of the two overnight interest rates.

\section{Methodology}

I replicate estimation equations (6) and (7) in Lee (2001) but replace the overnight Eurodollar rate with the Fed funds rate at 11:30 am. The methodology for testing the calendar-day effect on the Fed funds rate at 11:30 am is specified in equations (1) and (2) below. If day $t$ is the first day of the maintenance period or the first day of a quarter, the conditional mean of the Fed funds rate at 11:30 am is as follows

$$
\begin{aligned}
E\left(i_{t}^{11} \mid I_{t-1}\right)= & a_{1} i_{t-1}+a_{2} i_{t-2}+\cdots+a_{r} i_{t-r}+b_{1} i_{t-1}^{11}+b_{2} i_{t-2}^{11}+\cdots+b_{s} i_{t-s}^{11} \\
& +\eta_{1}+\sum_{j=1}^{8} \beta_{j} h_{j t} .
\end{aligned}
$$

On other days, it is

$$
\begin{aligned}
E\left(i_{t}^{11} \mid I_{t-1}\right)= & c_{1} i_{t-1}+c_{2} i_{t-2}+\cdots+c_{u} i_{t-u}+k_{1} i_{t-1}^{11}+k_{2} i_{t-2}^{11}+\cdots+k_{w} i_{t-v}^{11} \\
& +\sum_{s=2}^{10} \eta_{s} d_{s t}+\sum_{j=1}^{8} \beta_{j} h_{j t} .
\end{aligned}
$$

\footnotetext{
${ }^{1}$ The author is deeply grateful to James Hamilton for providing data.
} 
where $i_{t}$ is the effective Fed funds rate, $i_{t}^{11}$ is the Fed funds rate at 11:30 am and $d_{s t}$ and $h_{j t}$ are the dummy variables used in Lee (2001). The conditional mean specifications are different in accordance with whether or not day $t$ is the first day of the maintenance period or the first day of a quarter. The variable $d_{s t}$ for $s=2,3, \cdots, 10$ is a dummy variable to indicate day of the reserve maintenance period. Hence $s=2$ indicates the second day of the maintenance period, the first Friday, and $s=10$ the last day of the maintenance period, a settlement Wednesday. The variable $h_{j t}$ for $j=1,2, \cdots, 8$ is also a dummy variable to denote U.S. holidays and the last day of a quarter. The definitions of $d_{s t}$ and $h_{j t}$ are reported in Table II and Table III.

The error follows the Exponential GARCH (EGARCH) process

$$
i_{t}^{11}=E\left(i_{t}^{11} \mid I_{t-1}\right)+\sigma_{t} v_{t},
$$

where $v_{t}$ is a zero-mean i.i.d. random variable and $\sigma_{t}$ is a function of date $t$, lagged effective Fed funds rates and lagged Fed funds rates at 11:30 am. As in Lee (2001) and Hamilton (1996), $v_{t}$ is presumed to follow a mixture of Normal distributions to capture frequent small changes and infrequent large changes, which imply large kurtosis. The innovation $v_{t}$ is drawn from a $N(0,1)$ with probability $\mathrm{p}$ and from a $N\left(0, \tau^{2}\right)$ distribution, which has variance different from 1 with probability (1-p). The density of the mixture distribution is

$$
g\left(v_{t} ; \underline{\theta}\right)=\frac{p}{\sqrt{2 \pi}} \exp \left(\frac{-v_{t}^{2}}{2}\right)+\frac{1-p}{\tau \sqrt{2 \pi}} \exp \left(\frac{-v_{t}^{2}}{2 \tau^{2}}\right),
$$

where $\underline{\theta}$ is a vector of population parameters that includes $p$ and $\tau^{2}$. The conditional variance of this distribution is given by

$$
E\left\{\left[i_{t}^{11}-E\left(i_{t}^{11} \mid I_{t-1}\right)\right]^{2} \mid I_{t-1}\right\}=\sigma_{t}^{2}\left[p+(1-p) \tau^{2}\right] .
$$

I followed Hamilton's (1996) modification of Nelson's (1991) exponential GARCH model for the $\log$ of conditional variance of $i_{t}^{11}$. It is assumed that GARCH effects are integrated. I also accept the hypothesis of Hamilton (1996) that the most important determinants of the conditional variance are (1) the deviation of the log of the conditional variance from its unconditional expectation on the previous day and (2) the average 
difference between the log of the conditional variance and its unconditional expectation during the previous two-week maintenance period. Hence the log of $\sigma_{t}^{2}$ evolves according to

$$
\begin{aligned}
\ln \left(\sigma_{t}^{2}\right)-\sum_{s=1}^{10} \xi_{s} d_{s t}-\sum_{j=1}^{8} \kappa_{j} h_{j t} & =\delta\left[\ln \left(\sigma_{t-1}^{2}\right)-\sum_{s=1}^{10} \xi_{s} d_{s t-1}-\sum_{j=1}^{8} \kappa_{j} h_{j t-1}\right] \\
& +(1-\delta) \frac{1}{10} \sum_{m=b_{t}}^{l_{t}}\left[\ln \left(\sigma_{m}^{2}\right)-\sum_{s=1}^{10} \xi_{s} d_{s m}-\sum_{j=1}^{8} \kappa_{j} h_{j m}\right] \\
& +\alpha\left[q\left(v_{t-1}\right)-E q\left(v_{t-1}\right)+\aleph v_{t-1}\right],
\end{aligned}
$$

where $b_{t}$ and $l_{t}$ are the beginning and the ending days of the previous maintenance period respectively. The unconditional expectation of $\ln \sigma_{t}^{2}$ equals $\sum_{s=1}^{10} \xi_{s} d_{s t}+\sum_{j=1}^{8} \kappa_{j} h_{j t}$. I adopt the hypothesis of Hamilton (1996) that $\xi_{s}$ has the same value for day 2 to day 7:

$$
\xi_{2}=\xi_{3}=\cdots=\xi_{7} .
$$

The positive value of $(\alpha \cdot \aleph)$ indicates that volatility in conditional variance tends to rise when innovations of $i_{t}^{11}$ are positive. Because the nondifferentiability of the likelihood function makes it impossible to numerically maximize the likelihood at $v_{t-1}=0$, the function $q\left(v_{t-1}\right)$ takes the following form as Hamilton (1997) suggested:

$$
q\left(v_{t-1}\right)= \begin{cases}\left(1+v_{t-1}^{2}\right) / 2 & \text { for }\left|v_{t-1}\right|<1 \\ \left|v_{t-1}\right| & \text { for }\left|v_{t-1}\right| \geq 1\end{cases}
$$

This function is differentiable everywhere including $v_{t-1}=0$. The expected value of $q\left(v_{t-1}\right)$ is calculated by numerically integrating $q\left(v_{t-1}\right)$ with its density in the equation (4) with respect to $v_{t-1}$.

Since

$$
i_{t}^{11}=E\left(i_{t}^{11} \mid I_{t-1}\right)+\sigma_{t} v_{t}=\phi\left(v_{t}\right),
$$

the conditional density of $i_{t}^{11}$ would be

$$
f\left(i_{t}^{11} \mid I_{t-1}\right)=g\left(v_{t}\right)\left|\frac{d v_{t}}{d i_{t}^{11}}\right|
$$

where 


$$
v_{t}=\phi^{-1}\left(i_{t}^{11}\right)=\left\lfloor i_{t}^{11}-E\left(i_{t}^{11} \mid I_{t-1}\right)\right\rfloor / \sigma_{t}
$$

and $E\left(i_{t}^{11} \mid I_{t-1}\right)$ is specified in (1) and (2). Hence the log of the density is

$$
\ln f\left(y_{t} \mid I_{t-1}\right)=\ln \left[g\left(v_{t}\right)\right]-\ln \left(\sigma_{t}^{2}\right) / 2 .
$$

The EGARCH model is estimated by maximizing the conditional log likelihood with respect to the population parameters subject to two constraints, $0 \leq p \leq 1$ and $\tau^{2}>0$.

If the effects of calendar days on the Fed funds rate at 11:30 am are the same as those on the effective Fed funds rate, and if the differences between the Fed funds rate at 11:30 am and the effective Fed funds rate are not predictable based on the information set, then the predictable excess return on overnight Eurodollars is driven by the difference between the Fed funds market and the Eurodollar market. It is expected based on Griffiths and Winters (1995) that the morning Fed funds rate does not have a calendar day effect as big as the afternoon Fed funds rate. Therefore, if the effects of calendar days on the Fed funds rate at 11:30 am are the same as those on the overnight Eurodollar rate at 11:00 am GMT and the conditional expectation of the difference between the Fed funds rate at 11:30 am, and if the effective Fed funds rate has the positive $\operatorname{AR}(1)$ coefficient as does the conditional expectation of the difference between the overnight Eurodollar rate and the effective Fed funds rate, then the time difference in measuring data forces the excess return on overnight Eurodollars over Fed funds to be predictable.

\section{Empirical Results}

Equation (3) is estimated by maximum likelihood estimation for the mean parameters and the variance parameters. First, the conditional mean is discussed. If day $t$ is the first day of a maintenance period or the first day of a quarter, the conditional mean of the change in the Fed funds rate at 11:30 am is

$$
\begin{aligned}
E\left(i_{t}^{11}-i_{t-1}^{11} \mid I_{t-1}\right)= & 0.128 i_{t-1}+0.063 i_{t-2}+0.257 i_{t-3} \\
& (0.015) \quad(0.055) \quad(0.048) \\
- & 0.943 i_{t-1}^{11}+0.216 i_{t-2}^{11}+0.278 i_{t-3}^{11} \\
& (0.043)(0.063) \quad(0.051) \\
+ & \eta_{1}+\sum_{j=1}^{8} \beta_{j} h_{j t}
\end{aligned}
$$


where standard errors are in parentheses. If day $t$ is any other day, the maximum likelihood estimates are as follows:

$$
\begin{aligned}
E\left(i_{t}^{11}-i_{t-1}^{11} \mid I_{t-1}\right)= & 0.870 i_{t-1}-0.098 i_{t-2}-0.039 i_{t-3} \\
& (0.032) \quad(0.014) \quad(0.011) \\
& -0.847 i_{t-1}^{11}+0.076 i_{t-2}^{11}+0.035 i_{t-3}^{11} \\
& (0.034) \quad(0.017) \quad(0.012) \\
+ & \sum_{s=2}^{10} \eta_{s} d_{s t}+\sum_{J=1}^{8} \beta_{j} h_{j t} .
\end{aligned}
$$

Thus, the change in the Fed funds rate at 11:30 am, $i_{t}^{11}-i_{t-1}^{11}$, is predicted mainly by the difference between yesterday's effective Fed funds rate and yesterday's Fed funds rate at 11:30 am, $i_{t-1}-i_{t-1}^{11}$, among lagged interest rates. This result is similar to the estimation results of the conditional expectation for the overnight Eurodollar rate. The maximum likelihood estimates of dummy variables, $\eta_{s}$ and $\beta_{j}$, are reported in Table II and Table III. Table II and Table III also compare these maximum likelihood estimates of the dummy variable effects on the Fed funds rate at 11:30 am with those on the effective Fed funds rate and the overnight Eurodollar rate obtained by Lee (2001). ${ }^{2}$

\footnotetext{
2 I estimated the following equations by maximum likelihood for the effective Fed funds rate by using the data from March 1, 1984 to September 8, 1995. The independent variables of the effective Fed funds rate specification are lagged effective Fed funds rates, lagged Fed funds rates at 11:30 am and calendar day dummies. If day $t$ is the first day of a maintenance period or the first day of a quarter, the conditional mean of the effective Fed funds rate is described as follows:

$$
\begin{aligned}
E\left(i_{t} \mid I_{t-1}\right)= & -0.191 i_{t-1}+0.060 i_{t-2}+0.217 i_{t-3}-0.044 i_{t-1}^{11}+0.269 i_{t-2}^{11}+0.335 i_{t-3}^{11} \\
& (0.021) \quad(0.080) \quad(0.068) \\
+ & \eta_{1}+\sum_{j=1}^{8} \beta_{j} h_{j t} .
\end{aligned}
$$

For all other days, it is

$$
E\left(i_{t} \mid I_{t-1}\right)=i_{t-1}+\sum_{s=2}^{10} \eta_{s} d_{s t}+\sum_{j=1}^{8} \beta_{j} h_{j t} .
$$

The values of parameters of $\eta_{s}$ and $\beta_{j}$ are very similar to those of obtained by Lee (1999) where the independent variables are lagged effective Fed funds rates, lagged overnight Eurodollar rates and the dummy variables.

The conditional mean and the conditional variance of the overnight Eurodollar rate were also estimated by using equations (6) and (7) in Lee (1999) using the sample period from March 1, 1984 and to September 8, 1995. Maximum likelihood estimates are also very similar to those obtained in Lee (1999). For the first day of a maintenance period or the first day of a quarter, the conditional mean of the overnight Eurodollar rate is
} 
All statistically significant coefficients on the calendar-day dummies for the Fed funds rate at 11:30 am have the same signs as those for the effective Fed funds rate and those for the overnight Eurodollar rate, with the exception of $\eta_{6}$. The absolute values of $\eta_{s}$ and $\beta_{j}$ of the conditional mean of the effective Fed funds rate are greater than those of the Fed funds rate at 11:30 am, which is greater in absolute value than those of the overnight Eurodollar rate, with four exceptions. First Monday, second Thursday and second Monday effects $\left(\eta_{3}, \eta_{6}\right.$ and $\left.\eta_{8}\right)$ are higher for the Fed funds rate at 11:30 am than for the effective Fed funds rate. The effect of second Fridays $\left(\eta_{7}\right)$ on the Fed funds rate at 11:30 am is smaller in absolute value than on the overnight Eurodollar rate.

It needs to be determined whether estimated values for $\eta_{s}$ and $\beta_{j}$ are different for the Fed funds rate at 11:30 am, the effective Fed funds rate and the overnight Eurodollar rate. To check whether the calendar-day effects between the Fed funds rate at 11:30 am and the effective Fed funds rate are different, the following equation is estimated for the first day of the maintenance period and the first day of a quarter:

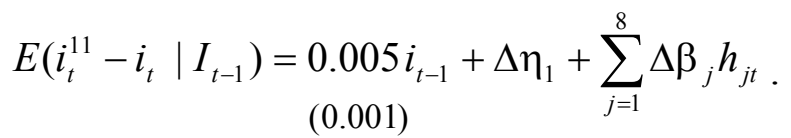

On other days, it is as follows:

$$
E\left(i_{t}^{11}-i_{t} \mid I_{t-1}\right)=\underset{(0.0231)}{0.2750 i_{t-1}^{11}-0.2768 i_{t-1}}+\sum_{s=2}^{s=10} \Delta \eta_{s} d_{s t}+\sum_{j=1}^{8} \Delta \beta_{j} h_{j t}
$$

$$
\begin{aligned}
& E\left(r_{t} \mid I_{t-1}\right)=0.077 i_{t-1}+0.154 i_{t-2}+0.086 i_{t-3}+0.056 r_{t-1}+0.364 r_{t-2}-0.261 r_{t-3} \\
& \begin{array}{llllll}
(0.018) & (0.060) & (0.056) & (0.071) & (0.083) & (0.055)
\end{array} \\
& +\eta_{1}+\sum_{j=1}^{8} \beta_{j} h_{j}
\end{aligned}
$$

For all other days, it is as follows:

$$
\begin{gathered}
E\left(r_{t} \mid I_{t-1}\right)=0.469 i_{t-1}-0.049 i_{t-2}-0.040 i_{t-3}+0.552 r_{t-1}+0.0641 r_{t-3} \\
(0.016) \quad(0.010) \\
+\sum_{s=2}^{10} \eta_{s}+\sum_{j=1}^{8} \beta_{j} h_{j}
\end{gathered}
$$

The values of parameters of $\eta_{s}$ and $\beta_{j}$ are also very similar to those in Lee (1999). 


$$
\approx 0.28\left(i_{t-1}^{11}-i_{t-1}\right)+\sum_{s=2}^{s=10} \Delta \eta_{s} d_{s t}+\sum_{j=1}^{8} \Delta \beta_{j} h_{j t} .^{3}
$$

The difference between the Fed funds rate at 11:30 am and the effective Fed funds rate is predicted by the difference between yesterday's Fed funds rate at 11:30 am and yesterday's effective Fed funds rate and calendar-day dummy variables. This result is the same as the difference between the overnight Eurodollar rate and the effective Fed funds rate in Lee (2001). On a day other than the first day of the maintenance period and the first day of a quarter ${ }^{4}$, the conditional mean of the difference of the overnight Eurodollar rate and the effective Fed funds rate is as follows in Lee (2001):

$$
\begin{aligned}
E\left(r_{t}-i_{t} \mid I_{t-1}\right)= & 0.475 r_{t}-0.478 i_{t-1}+\sum_{s=2}^{10} \Delta \eta_{s}+\sum_{j=1}^{8} \Delta \beta_{j} h_{j t} \\
& (0.019) \quad(0.019) \\
\approx & 0.48\left(r_{t-1}-i_{t-1}\right)+\sum_{s=2}^{10} \Delta \eta_{s}+\sum_{j=1}^{8} \Delta \beta_{j} h_{j t} .
\end{aligned}
$$

The autoregressive coefficient of the difference between the Fed funds rate at 11:30 am and the effective Fed funds rate is significant, as is the autoregressive coefficient of the difference between the overnight Eurodollar rate and the effective Fed funds rate. However, yesterday's difference between the Fed funds rate at 11:30 am and the effective Fed funds rate disappears more quickly today than yesterday's difference between the overnight Eurodollar rate and the effective Fed funds rate. These results indicate that the predictable difference between the overnight Eurodollar rate and the effective Fed funds rate could be ascribed to the market difference as well as to the time difference of measuring data.

A large body of research indicates that excess returns on the stock market, the foreign exchange market and the bond market are predictable (Cutler et al, 1991; Campbell and Hamao, 1992; Berkaert and Hodrick 1992; Ferson and Harvey, 1993; We

\footnotetext{
3 The likelihood ratio test rejects the null hypothesis that the coefficient of $i_{t-1}^{11}\left(\alpha_{1}\right)$ and the negative value of the coefficient of $i_{t-1}\left(-\alpha_{2}\right)$ are the same $\left(\alpha_{1}=-\alpha_{2}\right)$ because the standard errors of the two coefficients are very small. However the likelihood ratio test does not reject the null hypothesis of $\alpha_{1}+$ $0.001656=-\alpha_{2}$. Therefore, the relationship of $\alpha_{1}$ and $\alpha_{2}$ is considered to be $\alpha_{1}=-\alpha_{2}$.

${ }^{4}$ For the first day of the maintenance period and the first day of a quarter, the following estimates are the conditional mean in Lee (1999):$$
\begin{aligned}
E\left(r_{t}-i_{t} \mid I_{t-1}\right)= & -0.045 i_{t-1}+0.149 r_{t-1}+0.117 r_{t-2}+\Delta \eta_{1}+\sum_{j=1}^{8} \Delta \beta_{j} h_{j t} \\
& (0.017) \quad(0.022) \quad(0.021)
\end{aligned}
$$ 
and Ra, 1995; Harvey 1995; Canova and Marriano, 1995; Lo and Craig, 1997). A smaller literature also suggests the opportunity for excess returns in the money market. Campbell and Clarida (1987) document predictable time-vaying excess returns on Eurodeposits. Canova and Marrinan (1995) find that excess returns involving Eurodeposit, foreign exchange and bond markets are predictable using the information set of agents but no one instrument is jointly significant in predicting all excess returns in the US and UK. They also find some differences in the behavior of excess returns across holding periods of bonds.

If $\Delta \eta_{s}=0$ and $\Delta \beta_{j}=0$ in equations (15) and (16), there is no difference in the effects of calendar days on the conditional mean of the Fed funds rate at 11:30 am and the conditional mean of the effective Fed funds rate. Table IV and Table V report the values of $\Delta \eta_{s}$ and $\Delta \beta_{j}$ in equations (15) and (16) with those values for the difference between the overnight Eurodollar rate and the Fed funds rate at 11:30 am ${ }^{5}$ and for the difference between the overnight Eurodollar rate and the effective Fed funds rate reported in Lee (2001), which are the values of $\Delta \eta_{s}$ and $\Delta \beta_{j}$ in the above equation (17). The effects of the last day of a quarter is not discussed in this paper because they are not created by Federal Reserve regulations. The positive effect of the last day of a quarter is found in many financial markets as may researchers have found (Park and Reinganum, 1986; Allen and Saunders, 1992; Musto, 1997; Griffiths and Winters, 1997; Furfine, 1999). These authors show that financial instruments maturing across the year-end trade at a discount. This effect is explained by the motivation of window dressing or higher demand for liquidity but Furfine (1999) argued that this effect can not be explained by these reasons.

${ }^{5}$ If day $t$ is the first day of a maintenance period or the first day of a quarter, the estimated specification is as follows:

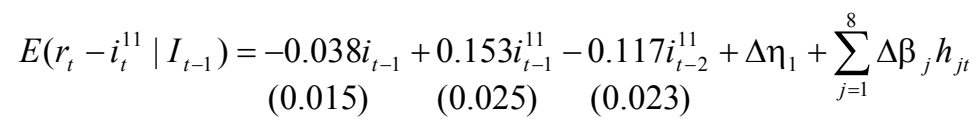

For other days, it is

$$
\begin{aligned}
E\left(r_{t}-i_{t}^{11} \mid I_{t-1}\right)= & -0.379 i_{t-1}+0.532 r_{t-1}-0.152 i_{t-1}^{11}+\sum_{s=2}^{10} \Delta \eta_{s} d_{s t}+\sum_{j=1}^{8} \Delta \beta_{j} h_{j t} \\
& (0.023) \quad(0.021) \quad(0.030) \\
= & -0.379\left(i_{t-1}-r_{t-1}\right)+0.152\left(r_{t-1}-i_{t-1}^{11}\right)+\sum_{s=2}^{10} \Delta \eta_{s} d_{s t}+\sum_{j=1}^{8} \Delta \beta_{j} h_{j t}
\end{aligned}
$$


The statistically significant effects of the day of the maintenance period and U.S. holidays on the conditional mean of the Fed funds rate at 11:30 am, the effective Fed funds rate and the overnight Eurodollar rate are categorized into four groups ${ }^{6}$. Only $\Delta \eta_{4}, \Delta \eta_{9}, \Delta \beta_{3}$ and $\Delta \beta_{4}$ are statistically significant among $\Delta \eta_{s}$ for $s=1,2, \cdots, 10$ and $\Delta \beta_{j}$ for $j=1,2, \cdots, 4$ of $E\left(i_{t}^{11}-i_{t} \mid I_{t-1}\right)$, and the five coefficients, $\eta_{3}, \eta_{6}, \eta_{8,} \eta_{10}$ and $\beta_{4}$, are statistically significant for $E\left(r_{t}-i_{t}^{11}\right)$. The first group is the estimated values for $\Delta \eta_{2}, \Delta \eta_{5}, \Delta \eta_{7}$ and $\Delta \beta_{2}$, which are not statistically significant in $E\left(i_{t}^{11}-i_{t} \mid I_{t-1}\right)$, $E\left(r_{t}-i_{t}^{11} \mid I_{t-1}\right)$ and $E\left(r_{t}-i_{t} \mid I_{t-1}\right)$. That is, the calendar day effects on the Fed funds rate at 11:30 am, the effective Fed funds rate and the overnight Eurodollar rate are the same on Fridays ( $s=2$ and 7), first Wednesday $(s=7)$ and the day before a three-day holiday $(j=2)$. All three interest rates tend to decrease at the same rate on Fridays, first Wednesdays and before a three-day holiday on average. The second group is the parameters $\Delta \eta_{3}, \Delta \eta_{6}, \Delta \eta_{8}$ and $\Delta \eta_{10}$, which are not significant in $E\left(i_{t}-i_{t}^{11} \mid I_{t-1}\right)$ but are significant in $E\left(r_{t}-i_{t}^{11} \mid I_{t-1}\right)$ and $E\left(r_{t}-i_{t} \mid I_{t-1}\right)$. The positive effects of Mondays ( $s=3$ and 8 ) and settlement Wednesdays $(s=10)$ on the Fed funds rate at 11:30 am and the effective Fed funds rate are the same but those effects are significantly smaller in absolute value on the overnight Eurodollar rate. The settlement Wednesday effect on the Fed funds rate at 11:30 am is different from the result of Griffiths and Winters (1995), who find that the morning Fed funds rate does not rise on settlement Wednesdays but the afternoon Fed funds rate rises significantly on settlement Wednesdays. The effects of Monday on the Fed funds rate and the overnight Eurodollar rate are positive. These results differ from the negative return on Monday shared by stocks and bonds presented by Rogalski (1984), Flannery and Protopapadakis (1988) and Wang, Li and Erickson (1997). Kamath, Whyte, Chatrath and Chaudhry (1995) investigate returns of Eurocurrency deposit including the 1-month, 2-month and 3-month rates and do not find the existence of a Monday effect for any Eurocurrency deposit rate. The Monday effect

\footnotetext{
${ }^{6}$ The only statistically significant $\eta_{s}$ and $\beta_{j}$ are discussed. The parameter $\eta_{1}$ is not significant in $E\left(i_{t} \mid I_{t-1}\right), E\left(i_{t}^{11} \mid I_{t-1}\right)$ and $E\left(r_{t} \mid I_{t-1}\right)$ but $\Delta \eta_{1}$ is significant in $E\left(r_{t}-i_{t}^{11} \mid I_{t-1}\right)$ and $E\left(r_{t}-i_{t} \mid I_{t-1}\right)$. However, because $\eta_{1}$ is not significant, $\Delta \eta_{1}$ is not discussed.
} 
on the overnight Eurodollar rate might come from an incentive of a U.S. bank which does not know whether it needs the full credit of a weekend loan and does not want to hold unwanted excess reserves. Second Thursdays $(s=6)$ have the same positive effect on the conditional mean of the Fed funds rate at 11:30 am and the effective Fed funds rate but they have a negative effect on the conditional mean of the overnight Eurodollar rate. The parameter estimates for $\Delta \eta_{4}, \Delta \eta_{9}$ and $\Delta \beta_{3}$ are in the third group. The negative effects of Tuesdays ( $s=4$ and 9) are the same for the Fed funds rate at 11:30 am and the overnight Eurodollar rate but they are larger in absolute value for the effective Fed funds rate than for the Fed funds rate at 11:30 am and the overnight Eurodollar rate. The effective Fed funds rate tends to increase but the Fed funds rate at 11:30 am and the overnight Eurodollar rate do not increase on average after a one-day U.S. holiday $(j=3)$. The parameter $\Delta \beta_{4}$ belongs to the fourth group. The parameter $\Delta \beta_{4}$ is statistically significant in $E\left(i_{t}^{11}-i_{t} \mid I_{t-1}\right), E\left(r_{t}-i_{t}^{11} \mid I_{t-1}\right)$ and $E\left(r_{t}-i_{t} \mid I_{t-1}\right)$. Following a 3-day holiday, the calendar day effect rate is largest for the effective Fed funds and smallest for the overnight Eurodollar rate $\left(\left[\beta_{4}\right.\right.$ in $\left.E\left(i_{t} \mid I_{t-1}\right)\right]>\left[\beta_{4}\right.$ in $\left.E\left(i_{t}^{11} \mid I_{t-1}\right)\right]>\left[\beta_{4}\right.$ in $\left.\left.E\left(r_{t} \mid I_{t-1}\right)\right]\right)$

These results suggest that the difference between the calendar day effects on the overnight Eurodollar rate at 11:00 am and those on the effective Fed funds rate is both due to features specific only to the overnight Eurodollar market and due to the time difference in measuring the two interest rates. The Fed funds rate and the overnight Eurodollar rate are affected by accounting conventions and line limits which exist in the Fed funds market so that they have similar calendar day effects with different magnitudes.

While the predictable difference between the Fed funds rate at 11:30 am and the effective Fed funds rate indicates an arbitrage opportunity by trading Fed funds at 11:30 am for Fed funds in the afternoon, the profit is very small. Hence, there is not much incentive for the Fed funds desk to take an arbitrage strategy.

The conditional variance of the Fed funds rate at 11:30 am follows a pattern similar to the conditional variance of the effective Fed funds rate and the conditional variance of the overnight Eurodollar rate obtained in Lee (2001) as reported in Tables VI and VII. 
The conditional variances of these three interest rates are higher on first Thursdays than on the next six business days. While the conditional variance of the effective Fed funds rate and the conditional variance of the overnight Eurodollar rate increases during the last three days of a maintenance period $\left(\xi_{10}>\xi_{9}>\xi_{8}>\xi_{j}\right.$ for $\left.j=1,2, \cdots, 7\right)$, the conditional variance of the Fed funds rate at 11:30 am increases only during the last two days of a maintenance period with the conditional variance on second Mondays as large as the conditional variance on second Tuesdays $\left(\xi_{10}>\xi_{9} \approx \xi_{8}>\xi_{j}\right.$ for $\left.j=2,3, \cdots, 7\right)$. The conditional variances of these three interest rates are largest on settlement Wednesday. The difference of the natural logarithm of $\sigma_{t}^{2}$ between settlement Wednesday and other days is larger in the effective Fed funds rate than in the Fed funds rate at 11:30 am by $\left(\xi_{10}-\xi_{2}\right.$ of the effective Fed funds rate $)-\left(\xi_{10}-\xi_{2}\right.$ of the Fed funds rate at 11:30 am)

$$
=(-1.182+3.846)-(-1.801+3.315)=1.15 .
$$

which means $\sigma_{t}^{2}$ of the effective Fed funds rate is 3 times larger than $\sigma_{t}^{2}$ of the Fed funds rate at 11:30 am on settlement Wednesday. The natural logarithm of $\sigma_{t}^{2}$ of the Fed funds rate at 11:30 am tends to be larger after a three-day holiday ${ }^{7}$ and around the last day of a quarter; this result is similar to the estimates for the natural logarithm of $\sigma_{t}^{2}$ of the effective Fed funds rate and of the overnight Eurodollar rate.

\section{Conclusion}

The calendar day effects which exist for the effective Fed funds rate are found in the Fed funds rate at 11:30 am. Four coefficients on the calendar dummies for the Fed funds rate at 11:30 am are smaller in the absolute value than those for the effective Fed funds rate, while five coefficients on the calendar day dummies for the Fed funds rate at 11:30 am are larger than those for the overnight Eurodollar rate. The difference between the Fed funds rate at 11:30 am and the effective Fed funds rate is positively correlated

\footnotetext{
7 The estimated value of $\kappa_{4}$ of the effective Fed funds rate was not significant in Lee (1999) with the sample period from March 1, 1984 to March 26, 1997. However, the estimated value of $\kappa_{4}$ of the effective Fed funds rate is significant in the estimation by using the sample period from March 1, 1984 to September 9, 1995.
} 
with its own lag as is the difference between the overnight Eurodollar rate and the effective Fed funds rate. The autoregressive coefficient of the former is smaller than that of the latter.

These results suggest that the predictable excess return on overnight Eurodollars over Fed funds in Lee (2001) can be explained by the time difference in measuring two interest rates as well as by the market differences between the Fed funds market and the overnight Eurodollar market. Therefore, these results imply that if the Fed funds rate and the overnight Eurodollar rate are measured at the same time, the effects of the calendar day on the overnight Eurodollar rate is much more similar with those on the Fed funds rate than the empirical results in Lee (2001). 


\section{References}

Allen, Linda and Anthony Saunders, 1992, Bank window dressing: theory and evidence, Journal of Banking and Finance 16, 585-623.

Bekaert, Geert and Robert J. Hodrick, 1992, Characterizing predictable components in excess returns on equity and foreign exchange markets, Journal of Finance 47(2), 467-509.

Campbell, John Y. and Ricahrd H. Clarida, 1987, The term structure of Euromarket interest rate: an empirical investigation, Journal of Monetary Economics 19, 25-44.

Campbell, John Y. and Yasushi Hamao, 1992, Predictable stock returns in the United States and Japan: a study of long-term capital market integration, Journal of Finance 47(1), 43-69.

Canova, Fabio and Jane Marrinan, 1995, Predicting excess returns in financial markets, European Economic Review 39, 35-69.

Cutler, David M, James M. Poterba and Lawrence H. Summers, 1991, Speculative Dynamics, Review of Economic Studies 58, 529-546.

Felson, Wayne e. and Campbell R. Harvey, 1993, The risk and predictability of international equity returns, Review of Financial Studies 6(3), 527-566.

Flannery, Mark J. and Aris A. Protopapadakis, 1988, From T-bill to common stocks: investigating the generality of intra-week return seasonality, Journal of Finance 43(2), 431-450.

Furfine, Craig, 1999, The Price of risk at year-end: evidence from interbank lending, Manuscript. Bank of International Settlements.

Griffiths, Mark D. and Drew B. Winters, 1995, Day-of-the-week effects in federal funds rates: further empirical findings, Journal of Banking and Finance 19, 1265-1284.

,1997, The effect of federal reserve accounting rules on the equilibrium level of overnight repo rates, Journal of Business Finance and Accounting 24(6), 815832.

Hamilton, James D., 1996, The daily market for federal funds, Journal of Political Economy 104(1), 22-56. 
, 1997, Measuring the liquidity effect, American Economic Review 87(1), 80-

97.

Harvey, Campbell R., 1995, Predictable risk and returns in emerging markets, Review of Financial Studies 8(3), 773-816.

Ho, Thomas S. and Anthony Saunders, A micro model of the federal funds market, Journal of Finance 15(3), 977-988.

Kamath, Ravindra, Ann Marie Whyte, Arijunchatrath and Mukesh Chudhry, 1995, Daily seasonals in the Eurocurrency market, American Business Review, January, 1-7.

Lee, Yungsook, 2001, The federal funds market and the overnight Eurodollar market, Discussion Paper . 2001/5, University of Nottingham.

Lo, Andrew. and A. Craig MacKinlay, 1997, Maximizing predictability in the stock and bond markets, Macroeconomic Dynamics 1(1), 102-1

Musto, David K, 1997, Portfolio disclosures and year-end price shifts, Journal of Finance 52, $1563-1588$

Nelson, Daniel, 1991, Conditional heteroskedasticity in asset return: a new approach, Econometrica 59(2), 347-370.

Park, San Yong and Marc R. Reinganum, 1986, The puzzling behavior of Treasury bills that mature at the turn of calendar months, Journal of Financial Economics 16, 267283.

Rogalski, Richard, 1984, New findings regarding day-of-the-week effects, Journal of Finance 39, 1603-1614.

Saunders, Anthony and Thomas Urich, 1988, The effects of shifts in monetary policy and reserve accounting regimes on bank reserve management behavior in the federal funds market, Journal of Banking and Finance 12, 523-535.

Singleton J. Clay and John R. Wingender, 1994, The nonparallel weekend effect in the stock and bond markets, Journal of financial Research 17(4), 531-538.

Spindt, Paul A. and J. Ronald Hoffmeister, 1988, The micromechanics of the federal funds market: implications for day-of-the-week effects in funds rate variability, Journal of Financial and Quantitative Analysis 23(4), 401-416.

Wang Ko, Yuming Le and John Erickson, 1997, A new look at the Monday effect, Journal of Finance 52, 2171-2186. 
We, Ferson and Korajczyk Ra, 1995, Do arbitrage pricing-models explain the predictability of stock returns, Journal of Business 68(3), 309-349. 
Figure I. The effective Fed funds rate and the Fed funds rate at 11:30 am

Panel A displays the daily effective Fed funds rate $i_{t}$. Panel B presents the Fed funds rate at 11:30 am, $i_{t}^{11}$. Panel C displays the differential between the effective Fed funds rate and the Fed funds rate at 11:30 am, $i_{t}^{11}-i_{t}$. 
Panel A: Effective Fed Funds Rate

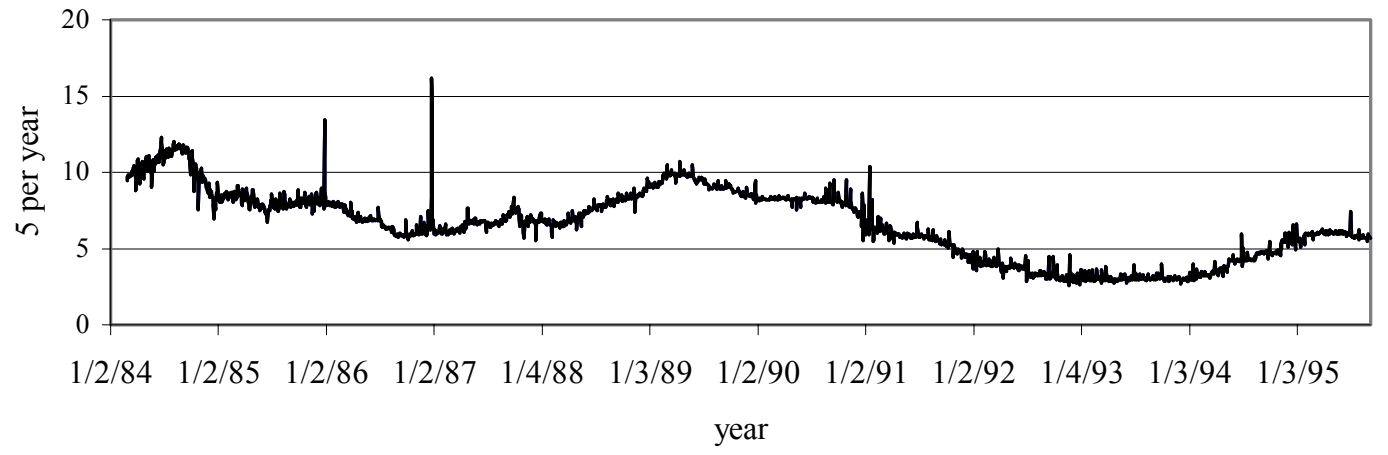

Panel B: Fed funds rate at 11:30 am

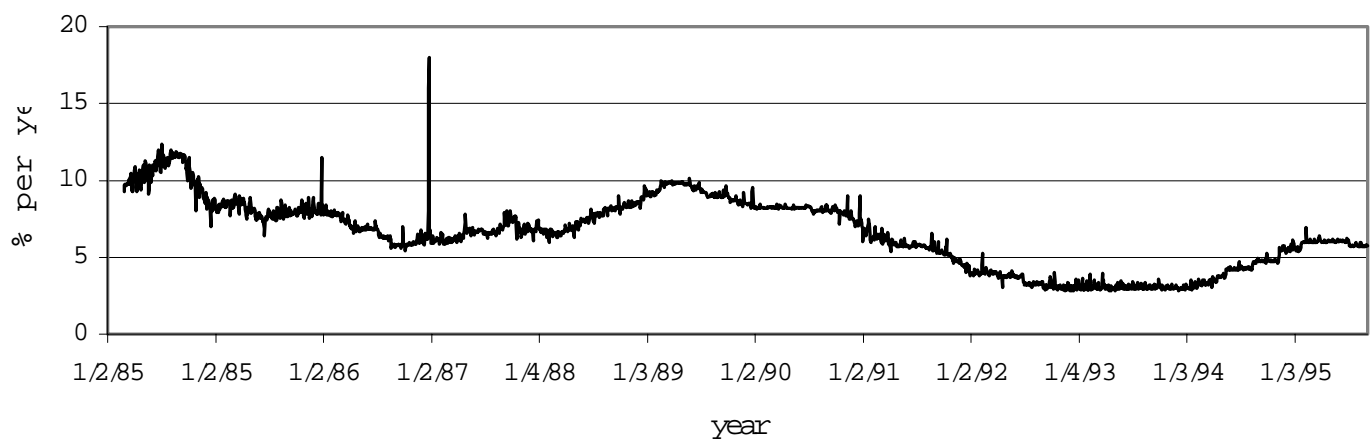

Panel C: The Differential between the Fed Funds Rate at 11:30 am and the Effective Fed Funds Rate

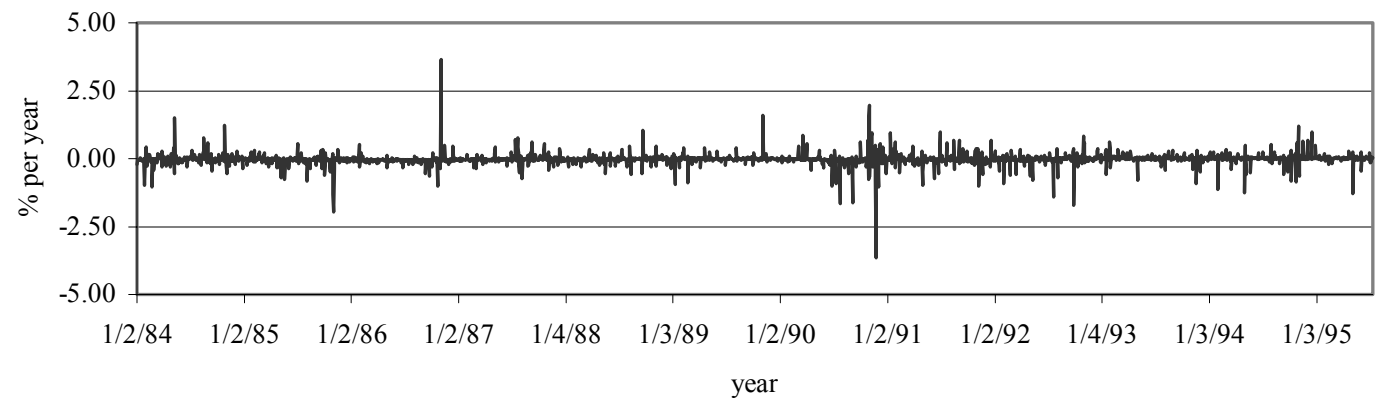




\section{Table I}

Summary Statistics for the Effective Fed funds Rate, the Fed Funds Rate at 11:30 and their

\section{Differential from 1984:03 to 1995:09}

The summary statistics are calculated from the effective Fed funds rate and the Fed funds rate at 11:30 am Eastern Standard Time. The sample period is from March 1, 1984 to September 8, 1995. The effective Fed funds rate on date $t$ is denoted $i_{t}$; the change of the effective Fed funds rare, $i_{t}-i_{t-1}$, is denoted $\Delta i_{t}$; the Fed funds rate at 11:30 on date $t$ is denoted $i_{t}^{11}$; the change in the effective Fed funds rate, $i_{t}^{11}-i_{t-1}^{11}$, is denoted $\Delta i_{t}^{11}$.

\begin{tabular}{crrrrc}
\hline & $i_{t}$ & $\Delta i_{t}$ & \multicolumn{1}{c}{$i_{t}^{11}$} & $\Delta i_{t}^{11}$ & $i_{t}^{11}-i_{t}$ \\
\hline Mean & 6.581 & -0.001 & 6.560 & -0.0001 & -0.021 \\
Maximum & 16.170 & 7.790 & 18.000 & 8.000 & 3.650 \\
Minimum & 2.580 & -7.789 & 2.810 & -8.620 & -3.640 \\
Std. Dev. & 2.247 & 0.389 & 2.239 & 0.338 & 0.217 \\
Skewness & 0.021 & 0.113 & 0.058 & -0.782 & -0.402 \\
Kurtosis & 2.382 & 134.705 & 2.535 & 266.157 & 73.771 \\
\hline
\end{tabular}




\section{Table II}

\section{Maximum Likelihood Estimates of the Conditional Mean ( day of the reserve maintenance period effects )}

The letter $s$ indicates which day of a two-week reserve maintenance period day $t$ falls on. For example, $s$ is equal to 1 if the day $t$ is the first Thursday of a maintenance period and $s$ is equal to 10 if the day $t$ is the last day of a maintenance period, which is a settlement Wednesday. The values of $\eta_{s}$ indicate the effect of the dummy variable for the day $s$ of the reserve maintenance period on the expected value of the effective Fed funds rate, the Fed funds rate at 11:30 am and the overnight London Interbank Offer Rate. The values, $\eta_{s}$, of the first column and the third column are maximum likelihood estimates of the conditional mean of the effective Federal funds rate specification and of the overnight London Interbank Offer Rate in Lee (2001). The values,

$\eta_{s}$ of the second column are maximum likelihood estimates for the conditional mean of the Federal funds rate at 11:30 am in equations (1) and (2). Standard errors are in parentheses.

\begin{tabular}{cccc}
\hline & $E\left(i_{t} \mid I_{t-1}\right)^{\mathrm{a}}$ & $E\left(i_{t}^{11} \mid I_{t-1}\right)$ & $E\left(r_{t} \mid I_{t-1}\right)^{\mathrm{a}}$ \\
\cline { 2 - 4 }$s$ & $\eta_{s}$ & $\eta_{s}$ & $\eta_{s}$ \\
\hline 1 & -0.007 & 0.001 & -0.017 \\
(first Thursday) & $(0.018)$ & $(0.023)$ & $(0.016)$ \\
2 & $-0.060^{* *}$ & $-0.043^{* *}$ & $-0.032^{* *}$ \\
(first Friday) & $(0.005)$ & $(0.008)$ & $(0.006)$ \\
3 & $0.056^{* *}$ & $0.068^{* *}$ & $0.028^{* *}$ \\
(first Monday) & $(0.005)$ & $(0.008)$ & $(0.005)$ \\
4 & $-0.053^{* *}$ & $-0.029^{* *}$ & $-0.012^{*}$ \\
(first Tuesday) & $(0.004)$ & $(0.007)$ & $(0.005)$ \\
5 & $-0.033^{* *}$ & $-0.017^{* *}$ & $-0.011^{*}$ \\
(first Wednesday) & $(0.004)$ & $(0.007)$ & $(0.005)$ \\
6 & $0.011^{* *}$ & $0.017^{*}$ & $-0.017^{* *}$ \\
(second Thursday) & $(0.004)$ & $(0.007)$ & $(0.005)$ \\
7 & $-0.042^{* *}$ & $-0.019^{* *}$ & $-0.023^{* *}$ \\
(second Friday) & $(0.004)$ & $(0.007)$ & $(0.005)$ \\
8 & $0.080^{* *}$ & $0.094^{* *}$ & $0.045^{* *}$ \\
(second Monday) & $(0.006)$ & $(0.008)$ & $(0.006)$ \\
9 & $-0.060^{* *}$ & $-0.017^{*}$ & 0.004 \\
(second Tuesday) & $(0.007)$ & $(0.008)$ & $(0.006)$ \\
10 & $0.137^{* *}$ & $0.118^{* *}$ & $0.052^{* *}$ \\
(second Wednesday) & $(0.016)$ & $(0.011)$ & $(0.007)$ \\
\hline denotes statistical significance at the 5\% level & & \\
** denotes statistical significance at the 1\% level & & \\
a Maximum likelihood estimates obtained in Lee (2001) & &
\end{tabular}


Table III

Maximum Likelihood Estimates of the Conditional Mean

( U.S. holiday and the last day of a quarter effects )

The letter $j$ indicates U.S. holidays and the last day of a quarter; $j=1$ indicates that day $t$ precedes a one-day holiday; $j=2$ indicates that day $t$ precedes a three-day holiday; $j=3$ indicates that day $t$ follows a one-day holiday; $j=4$ indicates that day $t$ follows a three-day holiday; $j=5$ indicates that day $t$ is the last day of $1^{\text {st }}, 2^{\text {nd }}, 3^{\text {rd }}$ or $4^{\text {th }}$ quarter; $j=6$ indicates that day $t$ is the last day of the year; $j=7$ indicates that day $t$ is one day before, on or one day after last day of $1^{\text {st }}, 2^{\text {nd }}, 3^{\text {rd }}$ or $4^{\text {th }}$ quarter; $j=8$ indicates that day $t$ is two days before, one day before, on, one day after or two days after the end of the year. The values of $\beta_{j}$ indicate the effects of the dummy variable $h_{j t}$ on the expected value of the effective Fed funds rate, the Fed funds rate at 11:30 am and the overnight London Interbank Offer Rate. The values $\beta_{j}$ of the first and third columns are maximum likelihood estimates for the conditional mean of the Federal funds rate specification in Lee (2001). The values $\beta_{j}$ of the second column are maximum likelihood estimates for the conditional mean of the Federal funds rate at 11:30 am in equation (1) and (2). Standard errors are in parentheses.

\begin{tabular}{cccc}
\hline \multirow{2}{*}{$j$} & $E\left(i_{t} \mid I_{t-1}\right)^{\mathrm{a}}$ & $E\left(i_{t}^{11} \mid I_{t-1}\right)$ & $E\left(r_{t} \mid I_{t-1}\right)^{\mathrm{a}}$ \\
\cline { 2 - 4 } & $\beta_{j}$ & $\beta_{j}$ & $\beta_{j}$ \\
\hline 1 & -0.027 & -0.036 & -0.003 \\
& $(0.024)$ & $(0.021)$ & $(0.015)$ \\
2 & $-0.024^{* *}$ & -0.013 & -0.008 \\
& $(0.008)$ & $(0.011)$ & $(0.008)$ \\
3 & $0.065^{* *}$ & 0.010 & -0.021 \\
& $(0.021)$ & $(0.016)$ & $(0.014)$ \\
4 & $0.198^{* *}$ & $0.145^{*}$ & $0.069^{* *}$ \\
& $(0.011)$ & $(0.016)$ & $(0.009)$ \\
5 & $0.340^{* *}$ & $0.259^{*}$ & $0.242^{* *}$ \\
& $(0.078)$ & $(0.048)$ & $(0.054)$ \\
6 & $-0.439^{*}$ & -0.065 & -0.052 \\
& $(0.192)$ & $(0.111)$ & $(0.112)$ \\
7 & 0.026 & 0.010 & -0.011 \\
& $(0.021)$ & $(0.015)$ & $(0.012)$ \\
8 & -0.046 & 0.037 & 0.027 \\
& $(0.052)$ & $(0.064)$ & $(0.031)$ \\
\hline
\end{tabular}

* denotes statistical significance at the $5 \%$ level

** denotes statistical significance at the $1 \%$ level

${ }^{a}$ Maximum likelihood estimates come from empirical results in Lee(2001). 


\section{Table IV}

Maximum Likelihood Estimates of the Conditional Mean

( day of the reserve maintenance period effects )

The letter $s$ indicates which day of a two-week reserve maintenance period day $t$ falls on. For example, $s$ is equal to 1 if the day $t$ is the first Thursday of a maintenance period and $s$ is equal to 10 if the day $t$ is the last day of a maintenance period, which is a settlement Wednesday. The

values of $\eta_{s}$ indicate the effect of the dummy variable for the day $s$ of the reserve maintenance period on the expected value of the difference of the Fed funds rate at 11:30 am and the effective Fed funds rate, the difference of the overnight Eurodollar rate and the Fed funds rate at 11:30 am, and the difference of the overnight London Interbank Offer Rate and the effective Fed funds rate. The values, $\eta_{s}$, of the third column are obtained in Lee (2001). Standard errors are in parentheses.

\begin{tabular}{cccc}
\hline & $E\left(i_{t}^{11}-i_{t} \mid I_{t-1}\right)$ & $E\left(r_{t}-i_{t}^{11} \mid I_{t-1}\right)$ & $E\left(r_{t}-i_{t} \mid I_{t-1}\right)^{\mathrm{a}}$ \\
\cline { 2 - 4 }$s$ & $\Delta \eta_{s}$ & $\Delta \eta_{s}$ & $\Delta \eta_{s}$ \\
\hline 1 & 0.009 & $-0.079^{* *}$ & $-0.037^{*}$ \\
(first Thursday) & $(0.010)$ & $(0.014)$ & $(0.017)$ \\
2 & 0.001 & -0.009 & 0.009 \\
(first Friday) & $(0.007)$ & $(0.013)$ & $(0.008)$ \\
3 & -0.003 & $-0.076^{* *}$ & $-0.057^{* *}$ \\
(first Monday) & $(0.006)$ & $(0.010)$ & $(0.007)$ \\
4 & $0.016^{*}$ & -0.004 & $0.030^{* *}$ \\
(first Tuesday) & $(0.007)$ & $(0.011)$ & $(0.007)$ \\
5 & 0.003 & -0.014 & 0.007 \\
(first Wednesday) & $(0.006)$ & $(0.010))$ & $(0.006)$ \\
6 & -0.009 & $-0.056^{* *}$ & $-0.043^{* *}$ \\
(second Thursday) & $(0.005)$ & $(0.010)$ & $(0.006)$ \\
7 & 0.009 & -0.019 & 0.009 \\
(second Friday) & $(0.006)$ & $(0.011)$ & $(0.008)$ \\
8 & -0.00001 & $-0.072^{* *}$ & $-0.049^{* *}$ \\
(second Monday) & $(0.007)$ & $(0.011)$ & $(0.008)$ \\
9 & $0.034^{* *}$ & 0.003 & $0.050^{* *}$ \\
(second Tuesday) & $(0.008)$ & $(0.010)$ & $(0.008)$ \\
10 & -0.032 & $-0.083^{* *}$ & $-0.107^{* *}$ \\
(second Wednesday) & $(0.017)$ & $(0.013)$ & $(0.019)$ \\
\hline
\end{tabular}

* denotes statistical significance at the $5 \%$ level

** denotes statistical significance at the $1 \%$ level

${ }^{a}$ Maximum likelihood estimates obtained in Lee(2001). 


\section{Table V}

\section{Maximum Likelihood Estimates of the Conditional Mean}

( U.S. holiday and the last day of a quarter effects )

The letter $j$ indicates U.S. holidays and the last day of a quarter; $j=1$ indicates that day $t$ precedes a one-day holiday; $j=2$ indicates that day $t$ precedes a three-day holiday; $j=3$ indicates that day $t$ follows a one-day holiday; $j=4$ indicates that day $t$ follows a three-day holiday; $j=5$ indicates that day $t$ is the last day of $1^{\text {st }}, 2^{\text {nd }}, 3^{\text {rd }}$ or $4^{\text {th }}$ quarter; $j=6$ indicates that day $t$ is the last day of the year; $j=7$ indicates that day $t$ is one day before, on or one day after last day of $1^{\text {st }}, 2^{\text {nd }}, 3^{\text {rd }}$ or $4^{\text {th }}$ quarter; $j=8$ indicates that day $t$ is two days before, one day before, on, one day after or two days after the end of the year. The values of $\beta_{j}$ indicate the effects of the dummy variable $h_{j t}$ on the expected value of the difference between the Fed funds rate at 11:30 am and the effective Fed funds rate, the difference between the overnight Eurodollar rate and the Fed funds rate at 11:30 am and the difference between the overnight London Interbank Offer rate and the effective Fed funds rate. The values $\beta_{j}$ of the third column are obtained in Lee (2001). Standard errors are in parentheses.

\begin{tabular}{cccc}
\hline \multirow{2}{*}{$j$} & $(4) E\left(i_{t}^{11}-i_{t} \mid I_{t-1}\right)$ & $(6) E\left(r_{t}-i_{t}^{11} \mid I_{t-1}\right)$ & $(5) E\left(r_{t}-i_{t} \mid I_{t-1}\right)^{\mathrm{a}}$ \\
\cline { 2 - 4 } & $\Delta \beta_{j}$ & $\Delta \beta_{j}$ & $\Delta \beta_{j}$ \\
\hline 1 & -0.0004 & 0.031 & 0.026 \\
& $(0.017)$ & $(0.020)$ & $(0.025)$ \\
2 & 0.012 & -0.004 & 0.015 \\
& $(0.015)$ & $(0.018)$ & $(0.011)$ \\
3 & $-0.046^{* *}$ & -0.053 & $-0.097^{* *}$ \\
& $(0.012)$ & $(0.031)$ & $(0.020)$ \\
4 & $-0.062^{* *}$ & $-0.101^{* *}$ & $-0.161^{* *}$ \\
& $(0.009)$ & $(0.011)$ & $(0.012)$ \\
5 & 0.040 & 0.015 & -0.120 \\
& $(0.083)$ & $(0.040)$ & $(0.095)$ \\
6 & 0.417 & -0.013 & 0.048 \\
& $(0.276)$ & $(0.118)$ & $(0.273)$ \\
7 & -0.014 & -0.028 & -0.029 \\
& $(0.029)$ & $(0.017)$ & $(0.027)$ \\
8 & 0.056 & -0.024 & 0.037 \\
& $(0.276)$ & $(0.039)$ & $(0.020)$ \\
\hline
\end{tabular}

$*$ denotes statistical significance at the 5\% level

** denotes statistical significance at the $1 \%$ level

${ }^{\text {a }}$ Maximum likelihood estimates obtained in Lee(2001) 


\section{Table VI \\ Maximum Likelihood Estimates of the Conditional Variance \\ (day of the reserve maintenance period effects)}

The letter $s$ indicates which day of a two-week reserve maintenance period day $t$ falls on. For example, $s$ is equal to 1 if the day $t$ is the first Thursday of a maintenance period and $s$ is equal to 10 if the day $t$ is the last day of maintenance day, which is a settlement Wednesday. The

values of $\xi_{s}$ indicate the effect of the dummy variable for the day $s$ of the reserve maintenance period on the natural log of the variance of the innovation in the Federal funds rate at 11:30 am, the effective Fed funds rate and the overnight Eurodollar rate respectively. The values, $\xi_{s}$, of the second and the third columns are maximum likelihood estimates for the conditional variance obtained in Lee (2001). Standard errors are in parentheses.

\begin{tabular}{|c|c|c|c|}
\hline & $E\left(i_{t}^{11} \mid I_{t-1}\right)$ & $E\left(i_{t} \mid I_{t-1}\right)^{\mathrm{a}}$ & $E\left(r_{t} \mid I_{t-1}\right)^{\mathrm{a}}$ \\
\hline $\mathrm{S}$ & $\xi_{s}$ & $\xi_{s}$ & $\xi_{s}$ \\
\hline 1 & $-2.896^{* *}$ & $-3.464 * *$ & $-3.487 * *$ \\
\hline (first Thursday) & $(0.332)$ & $(0.411)$ & $(0.534)$ \\
\hline 2 & $-3.315 * *$ & $-3.846^{* *}$ & $-4.409 * *$ \\
\hline (first Friday) & $(0.305)$ & $(0.401)$ & $(0.545)$ \\
\hline $\begin{array}{c}3 \\
\text { (first Monday) }\end{array}$ & $\{-3.315\}$ & $\{-3.846\}$ & $\{-4.409\}$ \\
\hline $\begin{array}{c}4 \\
\text { (first Tuesday) }\end{array}$ & $\{-3.315\}$ & $\{-3.846\}$ & $\{-4.409\}$ \\
\hline $\begin{array}{c}5 \\
\text { (first Wednesday) }\end{array}$ & $\{-3.315\}$ & $\{-3.846\}$ & $\{-4.409\}$ \\
\hline $\begin{array}{c}6 \\
\text { (second Thursday) }\end{array}$ & $\{-3.315\}$ & $\{-3.846\}$ & $\{-4.409\}$ \\
\hline $\begin{array}{c}7 \\
\text { (second Friday) }\end{array}$ & $\{-3.315\}$ & $\{-3.846\}$ & $\{-4.409\}$ \\
\hline $\begin{array}{c}8 \\
\text { (second Monday) }\end{array}$ & $\begin{array}{l}-2.907 * * \\
(0.324)\end{array}$ & $\begin{array}{l}-3.103 * * \\
(0.408)\end{array}$ & $\begin{array}{l}-3.985 * * \\
(0.558)\end{array}$ \\
\hline 9 & $-2.959 * *$ & $-2.839 * *$ & $-3.956 * *$ \\
\hline (second Tuesday) & $(0.340)$ & $(0.417)$ & $(0.543)$ \\
\hline $\begin{array}{c}10 \\
\text { (second Wednesday) }\end{array}$ & $\begin{array}{l}-1.801 * * \\
(0.322)\end{array}$ & $\begin{array}{l}-1.182 * * \\
(0.414)\end{array}$ & $\begin{array}{l}-3.225 * * \\
(0.551)\end{array}$ \\
\hline
\end{tabular}

** denotes statistical significance at the $1 \%$ level.

${ }^{a}$ Maximum likelihood estimates obtained in Lee(2001).

$\{\cdot\}$ indicates the restricted value. 


\section{Table VII}

\section{Maximum Likelihood Estimates of the Conditional Variance (holiday and the last day of a quarter effects)}

The letter $j$ indicates U.S. holidays and the last day of a quarter. $j=1$ indicates that day $t$ precedes a one-day holiday; $j=2$ indicates that day $t$ precedes a three-day holiday; $j=3$ indicates that day $t$ follows a one-day holiday; $j=4$ indicates that day $t$ follows a three-day holiday: $j=5$ indicates that day $t$ is the last day of $1^{\text {st }}, 2^{\text {nd }}, 3^{\text {rd }}$ or $4^{\text {th }}$ quarter; $j=6$ indicates that day $t$ is the last day of the year; $j=7$ indicates that day $t$ is one day before, on or one day after last day of $1^{\text {st }}, 2^{\text {nd }}, 3^{\text {rd }}$ or $4^{\text {th }}$ quarter; $j=8$ indicates that day $t$ is two days before, one day before, on, one day after or two days after the end of the year. The values of $\kappa_{j}$ indicate the effects of the dummy variable $h_{j t}$ on the natural $\log$ of the variance of the innovation in the Fed funds rate at 11:30 am, the effective Fed funds rate and the overnight Eurodollar rate respectively. The values, $\kappa_{j}$, of the second and the third columns are maximum likelihood estimates for the conditional variance of the effective Federal funds rate and the overnight Eurodollar rate obtained in Lee (2001). Standard errors are in parenthesis.

\begin{tabular}{cccc}
\hline$j$ & $E\left(i_{t}^{11} \mid I_{t-1}\right)$ & $E\left(i_{t} \mid I_{t-1}\right)^{\mathrm{a}}$ & $E\left(r_{t} \mid I_{t-1}\right)$ \\
\cline { 2 - 4 } & $\kappa_{j}$ & $\kappa_{j}$ & $\kappa_{j}$ \\
\hline 1 & $\{0.000\}$ & $\{0.000\}$ & $\{0.000\}$ \\
3 & $\{0.000\}$ & $\{0.000\}$ & $\{0.000\}$ \\
4 & $\{0.000\}$ & $\{0.000\}^{\mathrm{b}}$ & $\{0.000\}$ \\
& $0.758^{* *}$ & $\{0.000\}^{\mathrm{b}}$ & $\{0.000\}$ \\
5 & $(0.235)$ & & \\
& $1.295^{* *}$ & $2.020^{* *}$ & $2.658^{* *}$ \\
& $(0.366)$ & $(0.258)$ & $(0.331)$ \\
7 & $-1.700^{*}$ & -0.739 & -0.655 \\
& $(0.736)$ & $(0.521)$ & $(0.725)$ \\
8 & $0.868^{* *}$ & $1.353^{* *}$ & 0.332 \\
& $(0.257)$ & $(0.195)$ & $(0.223)$ \\
& $3.007^{* *}$ & $2.434^{* *}$ & $2.148^{*}$ \\
\end{tabular}

** denotes statistical significance at the $1 \%$ level

${ }^{a}$ Maximum likelihood estimates obtained in Lee (2001).

${ }^{\mathrm{b}}$ The estimate of $\kappa_{4}$ is 0.770 and is statistically significant at the $1 \%$ level if the sample is from March 1, 1984 to September 8, 1995.

$\{\cdot\}$ indicates the restricted value. 